\title{
BEYOND RECURSION: CRITIQUE OF HAUSER, CHOMSKY, AND FITCH
}

\author{
Roman Taraban \\ roman.taraban@ttu.edu \\ Achintha Bandara \\ achintha.bandara@ttu.edu \\ Texas Tech University, USA
}

Received November 29, 2017; Revised December 20, 2017; Accepted December 22, 2017

\begin{abstract}
In 2002, Hauser, Chomsky, and Fitch published an article in which they introduced a distinction between properties of language that are exclusively part of human communication (i.e., the FLN) and those properties that might be shared with other species (i.e., the FLB). The sole property proposed for the FLN was recursion. Hauser et al. provided evidence for their position based on issues of evolution. The question of the required properties of human language is central to developing theories of language processing and acquisition. In the present critique of Hauser et al. we consider two examples from non-English languages that argue against the suggestion that recursion is the sole property within the human language faculty. These are i) agreement of inflectional morphemes across sentence constructions, and ii) synthetic one-word constructions.
\end{abstract}

Keywords: recursion, inflectional morphology, synthetic languages

Тарабань Роман, Бандара Ахінта. Поза рекурсісю: критика Гаузера, Чамського та Фітча.

У 2002 році М. Гаузер, Н. Чамський та В. Т. Фітч опублікували статтю, в якій вони продемонстрували відмінність між властивостями мови, які є виключно частиною людського спілкування (FLN), та тими властивостями, які можуть бути спільними 3 іншими видами (FLB). Єдиною властивістю, запропонованою для FLN, була рекурсія. Гаузер та колеги у своїй позиції відштов хувалися від еволюційних засад. Питання про набуті властивості природної мови - центральне в розробці теорій обробки та оволодіння мови. У цій працікритиці Гаузера та колег ми пропонуємо два приклади з неанглійської мови, які заперечують те, що рекурсія - єдина властивість мовної здатності людини. Ці приклади включають: 1) узгодження морфем у всіх конструкціях речень, та 2) синтетичні однослівні конструкції.

Ключові слова: рекурсія, флективна морфологія, синтетичні мови.

\section{Introduction}

Since the time of the appearance of Chomsky's (1957) seminal work, Syntactic Structures, generative linguists have sought a set of universal properties that could account for the structure of specific languages. Linguistic universals include factors like word order (e.g., SVO), the placement of morphemes after the word they govern (i.e., postposition) or before the word they govern (i.e., preposition), and optional subjects in sentence construction (i.e., pro-drop languages). According to generative linguists, access to these principles and selection among them is part of an infant's innate endowment, and helps to explain the universal acquisition of natural language in infants. 
The universal properties of language are incorporated into language processing mechanisms for the configuration of specific languages. These linguistic properties operate within an encapsulated cognitive system, and they interface with general cognitive processes, but they are independent of those processes. More specifically, generative linguists assert that linguistic operations are separate from and independent of semantic processing and speech. In generative linguistic theories, the abstract principles that explain the properties of specific languages have been variously related to linguistic competence (vs performance), to linguistic essentialism, or to an internal language (I-language). ${ }^{1}$

A current position in the linguistic literature makes a distinction between FLB (Faculty of language - broad sense) and FLN (Faculty of language - narrow sense). This distinction was first articulated in Hauser et al. (2002), and we reference that article as our source for a description of the two components. Hauser et al. (2002) hypothesized that i) the distinction between FLN and FLB is central to understanding the nature of human language ability and ii) that the "FLN only includes recursion, and is the only uniquely human component of the faculty of language" (p. 1569). Recursion is defined by Hauser et al. as "the capacity to generate an infinite range of expressions from a finite set of elements" (p. 1569). FLB consists of the mechanisms for semantic analysis of the constructions generated by FLN and the articulatory processes involved in speech production.

An emphasis on recursion in Hauser et al. (2002) is not entirely new. Sauterland and Trotzke (2011) note that recursion was a central element of Chomsky's (1959) earlier work, where recursion was defined as self-embedding. For example, in the sentence, He said that he won, a sentence (he won) is embedded in a sentence (He said), or more generally speaking, a constituent of some kind is embedded within a constituent of the same kind. Chomsky's point was that phrase structure in human languages is highly productive, and is able to generate sentences of infinite length, and an infinite number of sentences, by nesting a function within itself. The operation of selfembedding mirrors the notion of recursion in Hauser et al. (2002).

Ott (2009) aptly summarized the relationships in generative theory between universal grammar, I-language, syntax, and recursion, as follows: "Minimally, the I-language must comprise a generative procedure (syntax) that operates over a finite lexicon of atomic units or words... and maps the resulting complex objects onto representations that are accessed by performance systems. Since syntactic operations apply recursively to atomic units and combinations thereof, the I-language yields an infinite array of structural descriptions linking 'sound and meaning', that is, representations encoding phonetic, semantic and structural properties" (p. 256).

It is important to consider the role of the lexicon when considering the FLN. Ott (2009) referred to "a finite lexicon of atomic units or words" in the preceding quote, which is consistent with the terminology of other generative linguists. Marantz (1997), for instance, described the lexicon as "a list of atomic elements for syntactic composition," "the source of items used by the compositional system of syntax," and he summarized the relationship between the lexicon and syntactic processor as follows: "[E]lementary constituents are drawn from a place called the "Lexicon" for composition in the syntax" (p. 201). From these descriptions it is

\footnotetext{
${ }^{1}$ https://plato.stanford.edu/entries/linguistics/
} 
clear that morphological elements are stored in the lexicon, but the composition of morphological elements is syntactic, not lexical.

The publication of Hauser et al. (2002) generated a number of reactions against the suggestion that recursion is the sole property of the FLN (Bickerton, 2009; Luuk \& Luuk, 2011, Ott, 2009; Sauerland \& Trotzke, 2011). Luuk and Luuk (2011) argued that recursion is not required for natural language, but a process of iteration is necessary. Recursion involves self-reference and invokes another instance of itself, as in the example above. Iteration does not involve self-reference, but can, nonetheless, implement phrase structure rules through iterative processing. Everett (2005) claimed that Pirahã did not use recursion and therefore recursion did not constitute a universal process in the FLN. However, his opponents claimed that he had misanalysed Pirahã (Nevins, Pesetsky, \& Rodrigues, 2009). Our goal here is not to evaluate the role of recursion in the human language faculty, but rather to consider whether recursion alone could be sufficient as the sole syntactic property of theFLN.

Other criticisms help to clarify the distinctions in Hauser et al. (2002) between the properties of FLN and FLB. Ott (2009), for example, argued that lexicalization is an essential component of the human language faculty. Lexicalization is the association of concepts with words, which function as grammatical units. Lexicalization provides the words on which I-language operates. The human capacity to generate units over which grammatical principles can operate yields the "unboundedness of human thought" (p.264). From Ott, we may conclude that FLN consists of syntactic operations operating on lexicalized concepts. Crucially, lexicalization allows concepts (lexicalized words) to enter into syntactic constructions. However, lexicalization draws on semantic information, therefore, is part of the FLB, not the FLN, according to Hauser et al.

Turning now to the present analys is, we ask whether there are other processes besides recursion that might be included in the FLN. In this critique, we suggest two possibilities: the agreement of morphological inflections within a sentence, and synthetic single-word constructions. To our knowledge, neither Hauser and colleagues, nor critics of FLN proposed these two linguistic processes as candidates for FLN.

\section{Methods}

The focus of the present analysis is on whether recursion can adequately account for the human language faculty. For the purpose of the present argument, we will assume that linguistic operations can be separated from the semantic processes that may be associated with the linguistic constructions, consistent with Hauser et al. (2002). There are several criteria that need to be fulfilled in order to present a valid case against the claim that recursion is the sole property of the FLN. These are the criteria:

- the operations in our examples are linguistic, not semantic or phonological, therefore, they qualify as belonging to FLN not FLB

- the operations in our examples do not involve recursion, therefore they are unique additions to the operation of the FLN 
- the operations function at the level of syntax, that is, the composition and agreement of linguistic morphemes across an extended construction, and cannot be readily attributed to lexical processing, specifically, to processes that would be completed with an individual's mental dictionary.

\section{The Study}

\subsection{Agreement of Inflectional Morphemes}

Natural languages can be classified as isolating, agglutinating, or inflectional. English tends towards an isolating language, with a phrase structure that lends itself to recursion, as defined by Hauser et al. (2002). English could be further described as an analytic language. Languages like Ukrainian, Russian, Polish, and Czech also provide for recursive processing of phrases. However, these languages also have a significant component of inflectional morphology, and are considered synthetic languages.

Slavic languages, like Ukrainian, Russian, Polish, Slovak and Czech, are inflectional, that is, they use inflectional morphemes to convey syntactic, grammatical, or semantic features. These languages inflect nouns, verbs, and adjectives. Nouns are inflected for case, gender and number. Verbs are inflected for tense, aspect, mood, person, subject number, and gender. Inflectional morphemes must be coordinated across the construction of a grammatical sentence. Therefore, agreement is syntactic, and agreement is required. Further, morphological inflections may be stored in a mental lexicon, but their agreement arises in syntactic processing, consistent with lexical-syntactic relationships in Ott (2009), Marantz (1997), and other generative linguists. Finally, to our knowledge, there is no evidence of the use of inflectional morphemes, like those for linguistic gender or case, in non-human species, so it does not violate the criterion to be included in the FLN in Hauser et al. (2002). Therefore, in consideration of these factors, agreement of inflectional morphemes qualifies as a property of the human language faculty. Examples of agreement of adjective-noun agreement (e.g., Інтелектуальна дівчина) and noun-verb agreement (e.g., дівчина пройшла) from several languages are as follows:

- Інтелектуальна дівчина склала іспит. (Ukrainian)

- Умная девушка сдала экзамен. (Russian)

- Inteligentna dziewczyna zdała egzamin. (Polish)

The intelligent girl passed the exam.

\subsection{One-Word Constructions in Synthetic Languages}

Agglutinated languages combine several morphemes into complex one-word constructions that can convey the equivalent meaning of a sentence. One-word constructions functioning as sentences can also be found in inflectional languages. In pro-drop languages, like Czech, Ukrainian, or Russian, an intransitive sentence can consist of only a verb; information about its subject is encoded in the verb. For example (Ukrainian):

- Пінов (He left)

Requests and imperatives can also consist of only a verb (Ukrainian):

- Послухайme (You) listen

- Проаналізуйmе (You) analyze this 
- Проходьme (You) pass through here.

Subjectless impersonals are another example of one-word constructions that function like sentences (Russian):

- Смеркалось (It got dusky)

As further examples of one-word constructions consider Sinhala, which is an Indo-Aryan language spoken in Sri Lanka. In Sinhala, similar to both Russian and Ukrainian, one-word constructions could be appear as requests and imperatives and subjectless impersonals. In volitive and non-volitive (inchoative) contexts subjectless impersonals are used as one-word utterances that carry syntactic elements such as embedded verb inflections, gender and word agreement, negation indicators and auxiliary ind icators. For example, following words show how one-word utterances are used

- Netenawa - I dance (I couldn't help that happened)

- Netawenawa - dance (someone is dancing involuntarily)

- Netennene - I do not dance (involuntary negation)

- Netennemane - I do not (ever) dance (involuntary negation with auxiliary indicator $-m a$ )

In $S$ inhala too, an intransitive sentence can consist of only a verb; information about its subject is encoded in the verb.

- Yayi-he/she/it is going

- Yathi - they are going

Especially honorific verbs are easily understood and used as one-word constructions that encode information about their subjects.

- Welanduwa (The priest ate food)

- Wediya (The priest came/ went)

However, in Sinhala, one-word constructions are most prominent and distinctive among imperatives. They can produce gender specific, subject indicated sentences by inflecting the root into more abstract longer verb forms. Parse trees in Figure 1 show the construction of Sinhalese imperatives. The construction can be described as an Inflectional Phrase (IP) with the positioning of affixes in rule form as:

[IP [Spec] [I' [VP [V] ] [Infl' [CASE.][Infl]]]].

An inflectional phrase (IP) of this form is a simple sentence. Spec (Specifier) bears inflectional properties such as tense and person. The other components of the IP are a verb phrase (VP), Case and inflection (Infl).

KEY

IP - Inflectional Phrase

Spec - Specifiers / Modalities

I' - Inflectional Predicate

VP - verb phrase

CASE - Case affixation

Infl - Inflection 


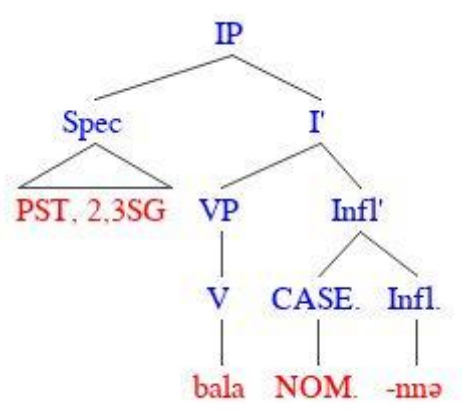

\author{
a- Balanna \\ Look
}

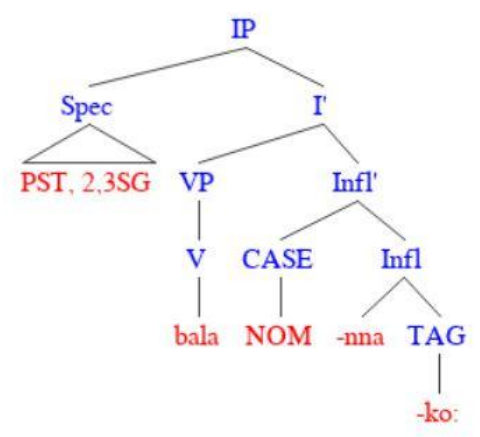

b- Balannako

Look, please / Please, look

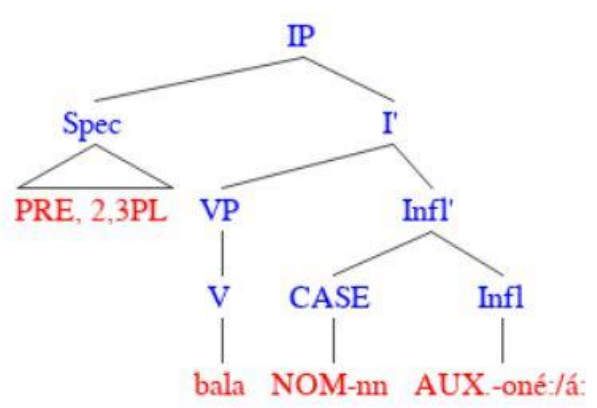

c- balannonela

look, should (2,3, SG,PL)

(He, she, it, they) Should look

d- Balawannemanedda?

Wouldn't (2,3 SG/PL) ever

make/ask someone to look (at

something)? Will you ask/ make

someone (2,3 SG/PL) (to) look (at

something) or not?

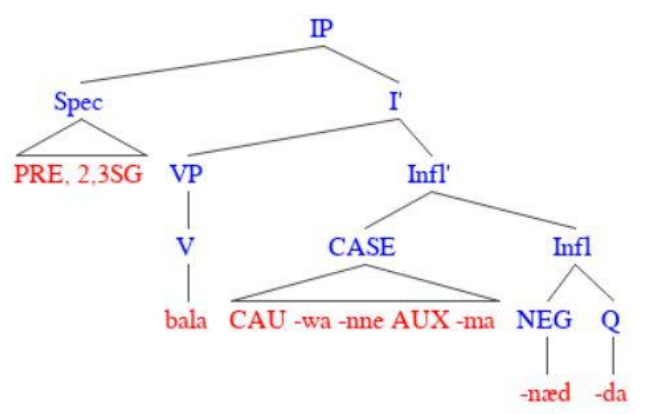

Fig. 1. Parse Trees for Sinhala Imperatives

More extensive examples in Table 1 show how imperatives in Sinhala are constructed to form complex meaningful units. Each word carries a root, case inflectional suffix, time modifier, gender marker and other grammatical indicators such as grammatical person markers $\left(1^{\text {st }}, 2^{\text {nd }}\right.$ or $\left.3^{\text {rd }}\right)$, auxiliary indicators and negation markers. These single agglutinative words form context-based utterances used with or without a noun phrase (NP).Thus, these constructions can stand alone as grammatical sentences that carry full meaning. The linguistic thought, or the consciousness of the speakers, would reflect morphological and syntactic agreements of these one-word constructions as abstract pragmatic syntactic structures. 
Table 1

\section{Examples of Sinhala Imperatives}

balann (Please) look (2,3 SG/PL)

Balannako Please look (2,3 SG/PL)

Balawann (Please) Make someone (2,3 SG/PL) look (at something); (Please) Ask someone (2,3 SG/PL) look (at something)

Balawannako Please, Make someone (2,3 SG/PL) look (at something); Please, Ask someone (2,3 SG/PL) look (at something)

Balawapan Make/ ask someone (2,3 SG/PL) look (at something) - derogatory form

Balanawada? Could you (please) look (at something); Could you look (derogatory form)

Balawanawada? Could you (please) make/ask someone (2,3 SG/PL) look (at something)

Balannenedda? Wouldn't you look (2, SG/PL)

Balawannenedda? Wouldn't you (2, SG/PL) make someone look (at something)

Baeluwada? Did you look?

Baelewwada? Did you make someone look (at something)?

Bala:palla: You all look (at something) (informal setting)

Balawapalla You all make someone (2,3 SG/PL) look (at something)?

Balapallako Could You all please look (at something) (informal setting)

Balawapallako Could you all please make someone (2,3 SG PL) look (at something)?

Balannoné:/á You should/must look (at something)

Balawannoné:/á You should/ must make someone (2,3, SG/PL) look (at something)

Balannamaone You must (with no exceptions) look (at something)

Balawannamaone You must (with no exceptions) make someone (2,3 SG/PL) look at something

Balnnemanedda? Wouldn't (2,3 SG/PL) ever look (at something)?; Will you ask (2,3 SG/PL) (to) look (at something) or not?

Balawannemanedda? Wouldn't (2,3 SG/PL) ever make/ask someone to look (at something)? Will you ask/ make someone (2,3 SG/PL) (to) look (at something) or not?

These constructions demonstrate a pattern of agglutinating, not recursion. The constituents (e.g., V, Infl) and categories (e.g., Case, IP) require syntactic processing for conjoining them and assuring agreement. Further, there is no evidence of which we are aware that would attribute these constructions to non-human species. Therefore, because these constructions are syntactic, do not involve recursion, and are uniquely human, they should be included in the FLN. Thus we would suggest that the suggestion in Hauser et al. (2002) that the FLN is limited to recursion is too restricted and does not acknowledge the significance of constructions in some languages that do not involve recursion.

\section{Conclusions}

The potential impact of Hauser, Chomsky, and Fitch (2002) on linguistic theory provides a strong incentive to reflect on the question of what linguistic representations and operations define the human language faculty. Hauser et al. are primarily interested 
in separating communicative functions that humans share with other species from those that are exclusively human. That may be one reason why they limit themselves to a single process, specifically, recursion, as constituting the FLN. However, we argue here that limiting the human language faculty to recursion is too conservative. The position espoused in Hauser et al. seems to be strongly conditioned (and misleading) by the isolating and analytic properties of English syntax. The English language does not employ extensive systems of morphological inflections and builds sentences word-byword and phrase-by-phrase, for the most part. This character of English may prompt linguists to downplay the nature of agglutinative languages, like Turkish, and fusional languages, like Ukrainian, Russian, Polish, etc. As we suggest here in our examples, the analytic and synthetic properties do not simply characterize Germanic languages but are also part of Aryan languages.

One interpretation of the suggestion in Hauser et al. (2002) that recursion "is the only uniquely human component of the faculty of language" (p. 1569) is as a variation of the Merge function in Chomsky's (1993) Minimalist program. Merge takes two syntactic units and conjoins them to form a new syntactic unit. In this sense, Merge might be viewed as having the embedding property attributed to recursion. Further, one could attribute the operation of feature checking (Adger, 2003) to the Merge function, which guarantees grammatical constructions, for instance, conjoining morphological features of gender across the constructed sentence. However, feature checking is clearly different from recursive embedding, which is precisely one of the points we are making in this paper. That is, feature checking is separate from the process of conjoining or agglutinating constituents. In the examples we provided here, the conjunction of morphemes does not involve recursion, but is clearly a significant component of syntactic construction.

As a final comment, Hauser et al. (2002) describe their interest as being about the computations underlying language processing, and not about the nature of language as a communicative system. By distancing themselves from the latter, they are implicitly reminding the reader of the unresolved conflicts between essentialist theorists and others, notably cognitive linguists and emergentists, that is, those theorists who assert that the "the forms of natural languages are created, governed, constrained, acquired and used in the service of communicative functions" (Bates \& MacWhinney 1982; MacWhinney \& O'Grady, 2015). According to these theories, a flawed assumption in Hauser et al. is the encapsulation and separation of the FLN from the FLB, that is from semantics and other essential processes in language production and comprehension involving perspective-taking and topic-comment, among others.

\section{References}

Adger, D. (2003). Core Syntax: A Minimalist Approach. Oxford: Oxford University Press.

Bates, E., \& MacWhinney, B. (1989). Functionalism and the Competition Model. In: The Crosslinguistic Study of Sentence Processing, (pp 3-76). B. MacWhinney and E. Bates (Eds.). New York: Cambridge University Press.

Chomsky, N. (1957). Syntactic Structures (2 ${ }^{\text {nd }}$ edition published in 2002). Berlin: Mouton

Chomsky, N. (1959). On certain formal properties of grammars. Information and Control, 2, 137 167. 
Chomsky, N. (1995). The Minimalist Program for Linguistic Theory. Cambridge, MA: MIT Press.

Bickerton, D (2009). Recursion: core of complexity or artifact of analysis? In: Syntactic Complexity: Diachrony, Acquisition, Neuro-Cognition, Evolution, (pp. 531-543). T. Givón and M. Shibatani (Eds.). Amsterdam: John Benjamins.

Hauser, M. D., Chomsky, N., Fitch, W. T. (2002). The faculty of language: What it is, who has it, and how did it evolve? Science, 298, 1569-1579.

Luuk, E., \& Luuk, H. (2011). The redundancy of recursion and infinity for natural language. Cognitive Processing 12, 1-11.

Marantz, A. (1997). No escape from syntax: Don't try morphological analys is in the privacy of your own lexicon. University of Pennsylvania Working Papers in Linguistics, 4(2), A. Dimitriadis, L. Siegel, et. al. (eds.), 201- 225.

MacWhinney, B. \& O'Grady, W. (Eds.) (2015). Handbook of Language Emergence. New York: Wiley.

Nevins, A., Pesetsky, D., \& Rodrigues, C. (2009). Pirahã exceptionality: A reassessment. Language, 85(2), 355-404.

Ott, D. (2009). The evolution of I-language: Lexicalization as the key evolutionary novelty. Biolinguistics, 3, 255-269.

Sauerland, U., \& Trotzke, A. (2011). Biolinguistic perspectives on recursion: Introduction to the special issue. Biolinguistics, 5, 1-9.

Trotzke, A., Bader, M. \& Frazier, L. (2013). Third factors and the performance interface in language design. Biolinguistics, 7, 1-34. 